\title{
Estratégia Anestesiológica para Cesariana em Paciente Portadora de Deficiência de Fator XI. Relato de Caso *
}

\author{
Anesthetic Strategy for Cesarean Section in a Patient with \\ Factor XI Deficiency. Case Report
}

\author{
Norma Sueli P. Módolo, TSA ${ }^{1}$, Vera Lucia Fernandes de Azevedo, TSA², Paulo Sérgio S. Santos, TSA ${ }^{3}$, Márcia Leal Rosa $^{4}$, \\ Dina Rita Corvino ${ }^{5}$ Lucas Jorge S. Castro Alves ${ }^{6}$
}

\section{RESUMO}

Módolo NSP, Azevedo VLF, Santos PSS, Rosa ML, Corvino DR, Alves LJSC - Estratégia Anestesiológica para Cesariana em Paciente Portadora de Deficiência de Fator XI. Relato de Caso.

JUSTIFICATIVA E OBJETIVOS: A deficiência do fator XI é uma doença hematológica rara na população. A hemofilia $C$ (deficiência do fator XI) ocorre em ambos os sexos e normalmente não apresenta qualquer sintomatologia, podendo manifestar-se apenas como hemorragia pós-cirúrgica. É uma doença autossômica recessiva, homozigótica ou heterozigótica, e sua gravidade depende dos níveis de fator XI. O objetivo desse relato foi apresentar a estratégia anestésica em paciente portadora de hemofilia $C$.

RELATO DO CASO: Paciente com 32 anos, gesta I/para 0, 39 semanas de gestação programada para cesariana eletiva. Paciente portadora de deficiência de fator XI. Exame clínico e laboratorial sem alterações. Conforme orientação do hematologista, no dia da cesárea a paciente usou prometazina $25 \mathrm{mg}$; hidrocortisona $500 \mathrm{mg}$, devido a reações transfusionais prévias, e plasma $10 \mathrm{~mL}^{-1} \cdot \mathrm{kg}^{-1}$ num total de $700 \mathrm{~mL}$. Após 2 horas foi submetida ao bloqueio subaracnóideo sob monitorização de rotina. Hidratação com RL 2000 mL. Procedimento anestésico-cirúrgico sem intercorrências. A paciente evoluiu no pós-operatório sem intercorrências, sendo que no $3^{\circ} \mathrm{DPO}$ fez uso de plasma fresco congelado (PFC) $10 . \mathrm{mL}^{-1} \cdot \mathrm{kg}^{-1} \mathrm{com}$ o objetivo de evitar sangramento pós cirúrgico tardio.

\footnotetext{
* Recebido (Received from) do Hospital Santo Amaro - Fundação José Silveira, Salvador, $B A$

1. Doutor em Anestesiologia; Professora Adjunta Livre-Docente da Universidade Estadual Paulista Júlio de Mesquita Filho

2. Mestre em Anestesiologia; Doutouranda em Anestesiologia - FMB/UNESP; Responsável pelo CET/SBA do Hospital Santo Antonio - Associação Obras Sociais Irmã Dulce

3. Mestre em Anestesiologia; Corresponsável pelo CET/SBA do Hospital Professor Edgar Santos da HUPES, Salvador, BA

4. Especialista em Anestesiologia; Anestesiologista do Hospital Santo Amaro 5. Especialista em Ginecologia e Obstetrícia; Obstetra do Hospital Santo Amaro

6. $M E_{1}$ do CET/SBA do Hospital Santo Antonio - Associação Obras Sociais Irmã Dulce
}

Apresentado (Submitted) em 17 de maio de 2009

Aceito (Accepted) para publicação em 24 de dezembro de 2009

Endereço para correspondência (Correspondence to):

Dra. Vera Lucia Fernandes de Azevedo

Rua Frederico Costa, 97/1001

Brotas

40255-350 Salvador, BA

E-mail:vlfazevedo@terra.com.br
CONCLUSÕES: O objetivo do caso foi apresentar o protocolo anestésico para pacientes portadores de hemofilia $C$ e alertar para a necessidade de investigação em caso de antecedente de sangramento pós-operatório, quando um estudo da coagulação deve ser realizado antes de qualquer procedimento invasivo e, se um TTPA prolongado for encontrado, torna-se imperativo pesquisar a deficiência desse fator.

Unitermos: ANESTESIA, Obstétrica; CIRURGIA, Obstétrica: cesariana; DOENÇAS, Hematológica: deficiência do fator XI, hemofilia C

\section{SUMMARY}

Módolo NSP, Azevedo VLF, Santos PSS, Rosa ML, Corvino DR, Alves LJSC - Anesthetic Strategy for Cesarean Section in a Patient with Factor XI Deficiency. Case Report.

BACKGROUND AND OBJECTIVES: Factor XI deficiency is a rare hematologic disorder. Hemophilia $C$ (factor XI deficiency) affects both genders and it is usually asymptomatic, manifesting only as postoperative hemorrhage. It is an autosomal recessive, homozygous or heterozygous, disorder, and its severity depends on the levels of factor $X I$. The objective of this report was to present the anesthetic strategy in a patient with hemophilia $C$.

CASE REPORT: This is a 32 years old female, gravida 1/para 0 , on the $39^{\text {th }}$ week of pregnancy, scheduled for elective cesarean section. Physical and laboratorial exams did not show any abnormalities. According to the recommendations of the hematologist, on the day of the procedure, the patient was given promethazine, $25 \mathrm{mg}$, hydrocortisone, $500 \mathrm{mg}$, due to prior transfusion reaction, and plasma, $10 \mathrm{~mL} . \mathrm{kg}^{-1}$ for a total of $700 \mathrm{~mL}$. Two hours later, the patient underwent subarachnoid block under routine monitoring. Ringer's lactate, $2000 \mathrm{~mL}$, was administered for hydration. The anesthetic-surgical procedure proceeded without intercurrences. Postoperatively, the patient was doing well when, on the $3^{\text {rd }} P O$ day, fresh frozen plasma (FFP), $10 \mathrm{~mL} . \mathrm{kg}^{-1}$, was administered to prevent late postoperative bleeding.

CONCLUSIONS: The objective of this report was to present the anesthetic protocol for patients with hemophilia $C$ and to alert for the need of investigation in patients with a history of postoperative bleeding, when a coagulation study should e be done before any invasive procedure and, in the case of prolonged aPTT, one should investigate the presence of factor XI deficiency.

Keywords: ANESTHESIA, Obstetrics; DISEASES, Hematological: factor XI deficiency, hemophilia C; SURGERY, Obstetric: cesarean section 


\section{Anesthetic Strategy for Cesarean Section in a Patient with Factor $\mathbf{X}$ Deficiency. Case Report}

Norma Sueli P. Módolo, TSA, M.D.; Vera Lucia Fernandes de Azevedo, TSA, M.D.; Paulo Sérgio S. Santos, TSA, M.D.; Márcia Leal Rosa, M.D.; Dina Rita Corvino, M.D.; Lucas Jorge S. Castro Alves, M.D.

\section{INTRODUCTION}

The following is a list of coagulation factors in the plasma: I fibrinogen; II - prothrombin; III - thromboplastin; IC - calcium; V - labile factor; VI - prothrombinase; VII - stable factor; VIII - antihemophilic globulin; IX - Christmas factor PTC; X - Stuart-Power factor; XI - PTA; XII - Hageman factor; XIII - fibrin stabilizing factor ${ }^{1}$.

According to the International Commission on Nomenclature of the World Health Organization (WHO), the classification of bleeding disorders is based on the deficient factor:

1) Fibrinogen I deficiency: afibrinogenemia, hypofibrinogenemia.

2) Deficiency of fibrin stabilizing factor XIII.

3) Prothrombin deficiency.

4) Deficiency of prothrombin activating factors:

a) Extrinsic pathways: factor $V$ deficiency or parahemophilia; factor VII deficiency; factor $X$ deficiency.

b) Intrinsic pathway: factor VIII deficiency (hemophilia A); factor IX deficiency (hemophilia B); factor XI deficiency (hemophilia C); factor XII deficiency (Hageman disease).

5) Deficiency associated with vascular and plasmatic factor (von Willebrand disease).

Factor XI deficiency or hemophilia $\mathrm{C}$ is a rare hematologic disease. Unlike hemophilia A (factor VIII deficiency), hemophilia $\mathrm{C}$ affects both genders and it is usually asymptomatic, manifesting only as postoperative bleeding ${ }^{2}$. It is an autosomal recessive disorder ${ }^{3,4}$, homozygous or heterozygous, and the severity depends on the levels of factor $\mathrm{XI}$, being classified as severe with levels of $4 \%$ to $20 \%$, and moderate to mild between $20 \%$ and $65 \%$.

Activation of factor $X$ is necessary for the conversion of prothrombin in thrombin and for the action of this compound on fibrinogen, transforming it in fibrin, followed by factor XIII, which stabilizes the fibrin clot. Factor VIII deficiency (hemophilia A), factor IX deficiency (hemophilia B), factor XI deficiency (hemophilia C), besides factor VII deficiency and the acquired deficiency of the inhibitors of those factors, are the most common hereditary disorders that compromise the activation of factor $\mathrm{X}$. Those deficiencies are translated in prolongation in activated partial thromboplastin time (aPTT), which, when present, should lead to the investigation of those factors or their inhibitors 6 . Factor $\mathrm{XI}$ has an important role in reducing fi- 
brinolysis, and patients with deficiency of this factor are prone to hemorrhagic episodes in tissues with increased fibrinolytic activity, such as tonsils, prostate, uterus, and oral cavity 5,7 . Factor XI has a half-life of 40 to 80 hours $^{5}$. A clear consensus on which level of factor $\mathrm{XI}$ is necessary for hemostasis during surgery does not exist, but the limit of $45 \mathrm{IU} \cdot \mathrm{dL}^{-1}$ and $30 \mathrm{IU} \cdot \mathrm{dL}^{-1}$ should be the goal for large and small surgeries, respectively ${ }^{5}$. Maintaining the levels of factor XI at approximately $30 \%$ is usually enough; however, some patients might need higher levels. The diagnosis of factor XI deficiency is confirmed by measuring its levels ${ }^{7}$. Patients with factor $\mathrm{XI}$ deficiency usually have prolonged aPTT and normal PT, although aPTT might be normal in heterozygous patients with mild deficiency. The levels of factors VIII and von Willebrand, as well as bleeding time and platelet function tests should also be investigated ${ }^{5,7}$, since it can be associated with platelet dysfunction. Prothrombin and thrombin time are normal in factor XI deficiency ${ }^{7}$.

\section{Situations and suggestions for the management of patients with hemophilia C:}

Preoperative: Fresh frozen plasma (FFP) $\left(15-20 \mathrm{~mL} \cdot \mathrm{kg}^{-1}\right)^{3-9}$, followed by postoperative maintenance with daily transfusion of FFP $\left(5 \mathrm{~mL} \mathrm{~kg}^{-1}\right)^{9}$ during one week, can be enough to prevent hemorrhagic complications after elective abdominal surgery in patients with severe factor XI deficiency ${ }^{5}$.

Vaginal delivery: FFP or factor XI concentrate during and/or after vaginal delivery is not mandatory in women with severe factor XI deficiency, and they can be restricted to patients with severe hemorrhage ${ }^{3}$.

Cesarean section: It seems that the same strategy (of the vaginal delivery) can be used ${ }^{3}$. It is possible that the tendency for bleeding complication after vaginal delivery or cesarean section is decreased due to the pregnancy-induced hypercoagulable state associated with high levels of fibrinogen and factors V, VII, VIII, IX, and XI'.

Epidural block: It is not recommended, being contraindicated in patients with severe factor XI deficiency, except if prophylactic treatment with FFP or factor XI concentrate is administered ${ }^{3}$.

Subarachnoid block: Safer than epidural block in patients with coagulopathies'.

Patients who develop inhibitors: During surgery, they can be treated with recombinant factor VIIa1.

Factor XI concentrate: This treatment is used in severe factor $\mathrm{XI}$ deficiency. The dose of $30{\mathrm{U} . \mathrm{kg}^{-1} \text { is recommended }}^{2-9}$.

Antifibrinolytic drugs used: Tranexamic acid, desmopressin, and fibrin glue ${ }^{2}$.

\section{CASE REPORT}

This 32 years old female, primigravida, on the $38^{\text {th }}$ week of pregnancy, was seen at the clinic for pre-anesthetic evaluation for cesarean section. The patient had factor XI deficiency followed-up by a hematologist. She had a history of myomectomy five years ago, during which she had severe postoperative bleeding; she was investigated at that time, receiving the diagnosis of factor XI deficiency. She had a history of several transfusions of FFP, and, on some occasions, she developed transfusional reactions. She stated she always had metrorrhagia which was explained as a consequence of uterine myomas.

Physical exam did not show any abnormalities, and preoperative laboratorial exams showed: hemoglobin 11 g.dL-1; hematocrit, 34\%; aPTT, 40 seconds; coagulation time, 8 minutes; bleeding time, 1 minute and 30 seconds; PT, normal; and INR, 1.0. According to the recommendations of the hematologist, on the day of the cesarean section the patient received oral promethazine $\left(25 \mathrm{mg} \mathrm{kg}^{-1}\right)$, and intravenous hydrocortisone (500 mg. kg ${ }^{-1}$ ) and $700 \mathrm{~mL}$ of plasma $\left(10 \mathrm{~mL} \cdot \mathrm{kg}^{-1}\right)$. Repeated aPTT $=34.4$ seconds. Two hours later, monitoring with cardioscope, pulse oximeter, non-invasive blood pressure, and urine output was instituted. A $27 \times 3.5$ Whitacre needle was used for the subarachnoid block, and $12.5 \mathrm{mg}$ of $0.5 \%$ hyperbaric bupivacaine and $50 \mu \mathrm{g}$ of morphine were administered. During the surgery, the patient received $2000 \mathrm{ml}$ of Ringer's lactate. Dexamethasone $\left(10 \mathrm{mg} \cdot \mathrm{kg}^{-1}\right)$ and ondansetron (4 $\mathrm{mg} \cdot \mathrm{kg}^{-1}$ ) were administered for prevention of nausea and vomiting, and cefazolin (2 mg. $\left.\mathrm{kg}^{-1}\right)$ was administered as antibiotic prophylaxis. Intercurrences were not observed during the anesthetic-surgical procedure and postoperative period; but on the $3^{\text {rd }}$ postoperative day, FFP $\left(10 \mathrm{~mL} \mathrm{~kg}^{-1}\right)$ was administered for prophylaxis of late postoperative bleeding.

\section{DISCUSSION}

Factor XI deficiency, or hemophilia C, was described by Rosenthal et al. in $1953^{-1}$. It has an incomplete autosomal recessive inheritance. Hemophilia $C$ has a frequency of $1 / 1,000,000$ in the general population, but it is higher in Ashkenazi Jews, with an estimated gene frequency between $5 \%$ and $11 \%$, and more than $0.3 \%$ are homozygous ${ }^{2,5-9}$. Deficiency results from three types of mutation: 1) changes in DNA segmentation, 2) interrupted DNA reading (stop codon), producing a non-functional molecule, and 3) amino acid substitution and molecular dysfunction 6 . Types II and III affect the ethnic group mentioned earlier ${ }^{7}$. It has few hemorrhagic manifestations, such as gingival bleeding, epistaxis, menorrhagia, and hematuria. However, significant bleeding can be seen after traumas or invasive procedures.

Factor XI deficiency interferes with the coagulation cascade because it is one of the factors of the intrinsic pathway for factor $\mathrm{X}$ activation. Fresh frozen plasma (initial dose $15 \mathrm{ml}^{\mathrm{kg}} \mathrm{kg}^{-1}$, followed by 3 to $6 \mathrm{ml}^{\mathrm{kg}} \mathrm{kg}^{-1}$ for 12 to 24 hours), or factor XI concentrate can be used in the treatment or prevention; the use of FEIBA (anti-inhibitor coagulant complex) is recommended ${ }^{8}$. In the case presented here, although the patient had a confirmed diagnosis of hemophilia $\mathrm{C}$, since the levels of factor XI were unknown, preoperative preparation was necessary. The objective of this report was to present the anesthetic protocol for patients with hemophilia $\mathrm{C}$, and to alert for the need to investigate cases with a prior history of postoperative bleeding; coagulation studies should be done before any invasive procedure and, if aPTT is prolonged, investigation of factor $\mathrm{XI}$ deficiency is mandatory. 


\section{REFERÊNCIAS - REFERENCES}

01. Ramos MRF, Rotbande IS, Ramos RRM - Complicação da anestesia subdural utilizada em artroscopia de joelho em paciente com doença de Von Willebrand: relato de caso. Rev Bras Ortop, 2000;35:419-421.

02. Conde P, Alegria A, Moniz A - Deficiência de factor XI. Acta Med Port, 2007;20:375-380.

03. Saloman O, Seligsohn U - New observations on factor XI deficiency. Haemophilia, 2004;10(suppl 4):184-187.

04. Bolton-Maggs PH - Factor XI deficiency and its management. Haemophilia, 2000;6(suppl 1):100-109.

05. Kim S, Srinivas SK, Rubin SC et al. - Delayed hemorrhage after cervical conization unmasking severe factor XI deficiency. Obstet Gynecol, 2004;104:1189-1192.

06. Diament J, Perez AR, Bacal NS et al. - Deficiência do fator XI. Einstein, 2004;2:115-116.

07. Canadian Hemophilia Society. Disponível em: http://www.hemophilia. $\mathrm{ca} / \mathrm{en} /$.

08. Rodgers GM, Grenberg CS - Inherited Coagulation Disorders, em: Lee GR, Foerster J, Lukens J et al. - Wintrobe's Clínical Hematology. $10^{\text {th }}$, Philadelphia, Lippincott Williams \& Wilkins, 1999;1712.

09. Martlew VJ - Peri-operative management of patients with coagulation disorders. Br J Anaesth, 2000;85:446-455.

\section{RESUMEN}

Módolo NSP, Azevedo VLF, Santos PSS, Rosa ML, Corvino DR, Alves LJSC - Estrategia Anestesiológica para Cesárea en Paciente Portadora de Discapacidad de Factor XI. Relato de Caso.
JUSTIFICATIVA Y OBJETIVOS: La discapacidad del factor XI es una enfermedad hematológica rara en la población. La hemofilia $C$ (discapacidad del factor XI), ocurre en los dos sexos y normalmente no presenta ninguna sintomatología, y se puede manifestar apenas como hemorragia post-quirúrgica. Es una enfermedad autosómica recesiva, homocigótica o heterocigótica, y su gravedad depende de los niveles de factor XI. El objetivo de este relato fue presentar la estrategia anestésica en paciente portadora de hemofilia $C$.

RELATO DEL CASO: Paciente con 32 años, gesta I/para 0, 39 semanas de gestación programada para cesárea electiva. Paciente portadora de discapacidad de factor XI. Examen clínico y laboratorial sin alteraciones. Conforme a la orientación del hematólogo, el día de la cesárea, la paciente usó prometazina $25 \mathrm{mg}$; hidrocortisona 500 $\mathrm{mg}$, debido a reacciones transfusionales previas, y plasma $10 \mathrm{~mL}^{-1}$. $\mathrm{kg}^{-1}$ llegando a un total de $700 \mathrm{~mL}$. Después de 2 horas, se sometió al bloqueo subaracnoideo bajo monitorización de rutina. Hidratación con RL $2000 \mathrm{~mL}$. Procedimiento anestésico-quirúrgico sin intercurrencias. La paciente evolucionó en el postoperatorio sin intercurrencias, y en el $3^{\circ}$ DPO usó plasma fresco congelado (PFC) $10 . \mathrm{mL}^{-1} \cdot \mathrm{kg}^{-1}$ para evitar el sangramiento post-quirúrgico tardío.

CONCLUSIONES: El objetivo del caso fue presentar el protocolo anestésico para pacientes portadores de hemofilia $C$ y alertar sobre la necesidad de investigación en caso de antecedente de sangramiento postoperatorio. También avisar cuando un estudio de coagulación debe ser realizado antes de cualquier procedimiento invasivo y si un TTPA prolongado se encuentra, es un imperativo investigar la discapacidad de ese factor. 